\title{
Efficacy of Intrauterine Hydrogen Peroxide and Povidone Iodine Administration to Treat Endometritic Mares
}

\author{
Jugraj Singh Mahal ${ }^{1}$, M. Honparkhe ${ }^{2 *}$, Ajeet Kumar ${ }^{3}$ and Prahlad Singh ${ }^{4}$ \\ ${ }^{1}$ Khalsa College of Veterinary and Animal Science, Amritsar, India \\ ${ }^{2}$ Department Veterinary Gynaecology and Obstetrics, Guru Angad Dev Veterinary and \\ Animals Sciences University, Ludhiana, Punjab 141004, India \\ *Corresponding author
}

\section{A B S T R A C T}

\begin{tabular}{l} 
K e y w o r d s \\
$\begin{array}{l}\text { Endometritis, } \\
\text { hydrogen peroxide, } \\
\text { mare, povidone }\end{array}$ \\
\hline Article Info \\
\hline $\begin{array}{l}\text { Accepted: } \\
\text { 20 February } 2020 \\
\text { Available Online: } \\
\text { 10 March } 2020\end{array}$ \\
\hline
\end{tabular}

The aim was to assess the comparative efficacy of intrauterine administration of hydrogen peroxide and povidone iodine solutions for the treatment of endometritis in indigenous mares. Twenty five mares with the history of regular estrus in a breeding season and turbid vaginal mucous discharge during estrus were included in the study. Following confirmation of endometritis through trans-rectal ultrasonography and uterine cytobrush, the animals were divided in to three groups at random on the basis of three intrauterine treatments. Group $\mathrm{I}(\mathrm{n}=15)$ received $0.5 \%$ povidone solution $2.5 \mathrm{ml}$ in $500 \mathrm{ml}$ normal saline intrauterine on day 0 (day of presentation) followed by $500 \mathrm{ml}$ intrauterine normal saline and intramuscular 20 I.U. oxytocin 6-8 h later. Group II(n=15) administered with $60 \mathrm{ml}$ hydrogen peroxide (3\%) intrauterine on day 0 followed by $500 \mathrm{ml}$ intrauterine normal saline and intramuscular 20 I.U. oxytocin6-8 h later. Group $\operatorname{III}(\mathrm{n}=5)$ received $500 \mathrm{ml}$ intrauterine normal saline on day 0 followed by 20 I.U. oxytocin intramuscularly. The natural mating was advised during subsequent estrus if the vaginal mucus discharge found apparently clear. Post-treatment cure rates based on clear vaginal mucus were $60 \%, 80 \%$ and $40 \%$ in Group I, II and III, respectively. The conception rates were higher $(\mathrm{P}<0.05)$ in Group I and II versus Group III $(55.5 \%, 66.6 \%$ vs 50\%, respectively). The intrauterine hydrogen peroxide and povidone iodine treatment proved beneficial to treat endometritic mares.

\section{Introduction}

The mares suffer from various reproductive problems such as repeat breeding, an estrous, endometritis, abortions, retention of placenta and dystocia etc. Amongst all these disorders, endometritis has been reported to be the third most common medical condition in mares (Card 2005, Rasmussen et al., 2015) and is an important cause of reduced fertility. The mares if affected with persistent uterine infection may undergo abortions at various stages of gestation (Laugier et al., 2011). Following uterine fluid accumulation, the uterine defence mechanisms is compromised due to reduced phagocytosis, mucociliary clearance and lymphatic drainage resulting in to chronic endometrial dysfunction (Leblanc 
and Causey, 2009). More commonly, antibiotics are used in mares (Ferris, 2017) to treat reproductive tract infections but with variable success rate. Treatment failure may be because of presence of uterine exudates, mucus or biofilm produced by some bacteria and yeast (Buczkowska et al., 2015).

Besides this, antibiotics often requires frequent administration, have high cost and results into development of microbial resistance, and decrease in phagocytic activity of polymorphonuclear cells (Chastantmaillard, 2006). In view of this, the present study was aimed to assess the comparative efficacy of the commonly available chemicals viz. povidone iodine and hydrogen peroxide for the treatment of endometritis in indigenous mares.

\section{Materials and Methods}

A total of thirty five problematic cyclic indigenous mares (Marwari breed) presented to university clinics during the period of last three years were selected for the study. The inclusion criteria for the mare were on the basis of history of non-conception despite several attempts of breeding, exhibiting estrus signs and had cloudy/turbid/mucopurulent vaginal mucus discharge. These mares were otherwise free from any congenital, metabolic, musculoskeletal disorders. Regular deworming was also practiced in these mares.

Prior to treatment, all the mares were subjected to B-mode transrectal ultrasonography to visualize presence of uterine oedema (grade $\geq 3$, Samper et al., 2007) and presence of follicle $>30 \mathrm{~mm}$ diameter on either of the ovaries.

The uterine cytobrush samples (for \% PMNs) were also taken to confirm endometritis. The cytobrushsmears were prepared and stained with Modified Wright Giemsa stain (SigmaAldrich Inc., USA) as per the guidelines. The undiluted neat stain was added and kept for 2 minutes and then diluted with double volume of distilled water and kept for 5 minutes and finally washed with triple glass distilled water. Slides were air dried and examined using light microscope under oil immersion at 100x magnification to identify individual cell type, including polymorphonuclear (PMNs) and endometrial epithelial cells.

The counting of 200 cells per slide with $2 \%$ PMNs cut off was considered for confirming endometritis. Following confirmation of endometritis with the help of clinical signs (mucopurulent/turbid/cloudy cervico-vaginal mucus), ultrasonographic characteristics (presence of anechoic fluid with echogenic spots of pus/tissue debris and uterine oedema $\geq 3$ grade) and PMN cells ( $\geq 2 \%$ ), the mares were divided in to three groups at random on the basis of treatment (Figure 1) as follow:

Group I $(\mathrm{n}=15)$-received $0.5 \%$ povidone solution i.e. $2.5 \mathrm{ml}$ dissolved in $500 \mathrm{ml}$ normal saline intrauterine on day 0 (day of presentation)followed by intrauterine infusion of $500 \mathrm{ml}$ normal saline $6-8 \mathrm{~h}$ later. Subsequently, 20 I.U. oxytocin was administered intramuscularly within 10 minutes.

Group II ( $\mathrm{n}=15)$-administered with hydrogen peroxide $(60 \mathrm{ml}, 3 \%)$ intrauterine on day 0 followed by intrauterine infusion of $500 \mathrm{ml}$ normal saline 6-8 h later. Following this an intramuscular injection of 20 I.U. oxytocin was given within 10 minutes.

Group III ( $\mathrm{n}=5)$-received $500 \mathrm{ml}$ intrauterine normal saline on day 0 followed by 20 I.U. oxytocin intramuscularly $10 \mathrm{~min}$. later.

During next subsequent estrus, the mares from all the groups were again subjected to transrectal ultrasonography and uterine cytobrush sample. 
The mares were allowed to be covered (two coverings at 36 hrs interval) depending upon signs of estrus (clear CVM), PMN cells $(<2 \%)$ and uterine edema grade $(\leq 3)$. The pregnancy diagnosis was done after 21 days of last covering in all the groups by transrectal ultrasonography.

The PMNs percentage and uterine oedema gradepre and post treatment in different groups were presented as Mean \pm SEM.The comparison of cure rate and conception rates were analysed by chi square test.

\section{Results and Discussion}

Mean \pm SEM values for pre and post treatment $\%$ PMN, uterine oedema grades, cure rate and conception rates are depicted in Table 1.There was significant decrease observed in \% PMN and uterine oedema grade during subsequent estrus following both the treatments whereas in control group \% PMN remained similar.

The cure rate on the basis of clear vaginal mucus in subsequent estrus was significantly $(\mathrm{P}<0.05)$ higher in group I and II as compared to control ones. Endometritis due to bacterial infection is considered as a major cause of non-conception because persistent endometritis delays the clearance of mucus and causes its accumulation within the uterine lumen (Troedsson,2007).

The gram negative bacteria such as E.coli, $P$.aeruginosa, and K. pneumoniae are capable of producing mucus biofilm in uterus that is a common survival strategy employed by bacteria. It confers resistance to antimicrobial agents and also prevents bacterial clearance mediated by the host immune response. The immune system of host is often unable to recognize and clear biofilm associated infections due to thick layer of exo polysaccharide that prevents antibodies to influence the bacteria residing within the biofilm and impeding the function and phagocytic ability of macrophages and neutrophils (Ferris et al., 2016).

The formation of biofilm during oestrus or after breeding causes inhibition of forward progression of spermatozoa in the uterine lumen that is subsequently responsible for reduced pregnancy rates in mares (Rutllant et al., 2005). Weak solutions of hydrogen peroxide is beneficial in acute endometritis when exudates is found in the uterine lumen.

Hydrogen peroxide causes disruption of preformed biofilms over endometrium however, the sensitivities to disruption differs according to the bacterial strains (Ferris et al., 2016). Following phagocytosis by neutrophils, bacteria are destroyed partially by oxidative metabolism that involves hydrogen peroxide (Wolfsdorf\& Caudle, 2007).

Irrigation with dilute iodine solutions has been recommended specifically more dilute solution $(0.5 \%$ povidone iodine $)$ for the treatment of uterine infections (Ricketts, 1999). Troedsson (2011) also suggested that a very dilute solution $(0.05-0.10 \%)$ of povidone iodine in lactated ringer solution may be beneficial for treating endometritis in mares.

Due to lack of available literature, the data pertaining to conception following hydrogen peroxide and povidone treatment could not be compared with previous studies. Hence, it is concluded that the non-antibiotic intrauterine treatment with povidone iodine and hydrogen peroxide can be effectively used to improve cure and conception rate in endometritic mares. 
Table.1 Pre and post treatment Mean \pm SEM \% PMN and uterine edema grades in different groups

\begin{tabular}{|l|c|c|c|c|c|c|}
\hline \multicolumn{1}{|c|}{ Observation } & \multicolumn{2}{|c|}{$\begin{array}{c}\text { Group I } \\
\text { (Povidone-Iodine) }\end{array}$} & \multicolumn{2}{c|}{$\begin{array}{c}\text { Group II } \\
\text { (Hydrogen peroxide) }\end{array}$} & \multicolumn{2}{c|}{$\begin{array}{c}\text { Group III } \\
\text { (Normal saline) }\end{array}$} \\
\hline & $\begin{array}{c}\text { Pre- } \\
\text { treatment }\end{array}$ & $\begin{array}{c}\text { Post } \\
\text { treatment }\end{array}$ & $\begin{array}{c}\text { Pre- } \\
\text { treatment }\end{array}$ & $\begin{array}{c}\text { Post } \\
\text { treatment }\end{array}$ & $\begin{array}{c}\text { Pre- } \\
\text { treatment }\end{array}$ & $\begin{array}{c}\text { Post } \\
\text { treatment }\end{array}$ \\
\hline PMNs (\%) & $4.5 \pm 0.3^{\mathrm{a}}$ & $1.5 \pm 0.1^{\mathrm{b}}$ & $3.8 \pm 0.1^{\mathrm{a}}$ & $1.7 \pm 0.2^{\mathrm{b}}$ & $3.6 \pm 0.2$ & $3.0 \pm 0.3$ \\
\hline Uterine edema grade & $3.6 \pm 0.1^{\mathrm{a}}$ & $2.5 \pm 0.1^{\mathrm{b}}$ & $3.4 \pm 0.1^{\mathrm{a}}$ & $2.6 \pm 0.1^{\mathrm{b}}$ & $3.6 \pm 0.1$ & $3.4 \pm 0.1$ \\
\hline Cure rate (\%) & \multicolumn{2}{|c|}{$60(\mathbf{9} / \mathbf{1 5 )}$} & \multicolumn{2}{|c|}{$80(12 / 15)$} & $40(2 / 5)$ \\
\hline Conception rate (\%) & \multicolumn{2}{|c|}{$55.5(5 / 9)^{*}$} & \multicolumn{2}{|c|}{$66.6(8 / 12)^{*}$} & & $50(1 / 2)$ \\
\hline
\end{tabular}

${ }^{\mathrm{a}, \mathrm{b}}$ Values with different superscripts are significant $(\mathrm{P}<0.05)$ in a same group pre and post treatment *Significant $(\mathrm{P}<0.05)$ than Group III

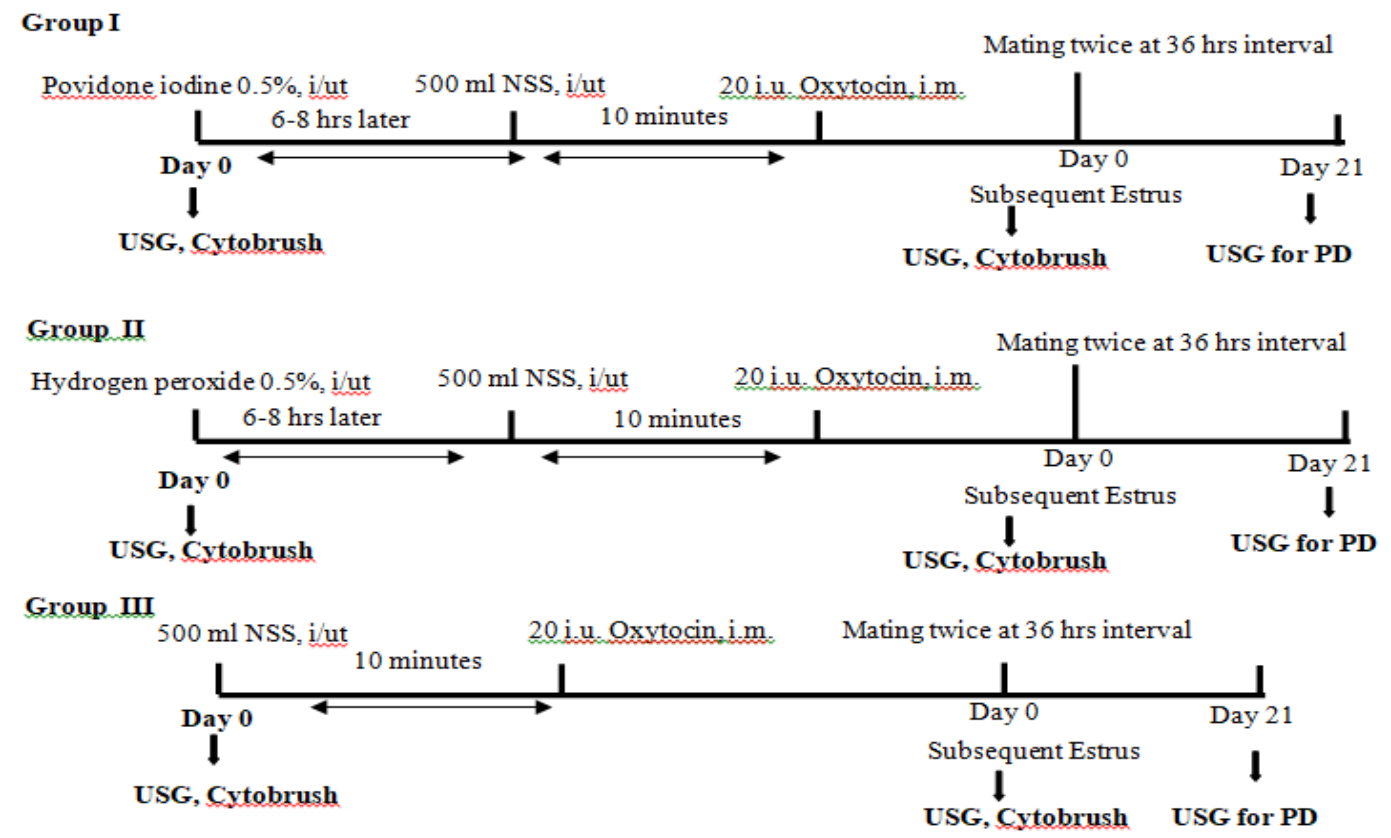

Figure.1 The treatment protocols used in different groups of endometritic mares. USG-ultrasonography, NSS-normal saline solution, PD-pregnancy diagnosis

\section{Acknowledgements}

The authors are thankful to ICAR for providing funds under CAFT (Centre for advanced faculty training at Department of Veterinary Gynaecology and Obstetrics, GADVASU, Ludhiana) that helped us to conduct this study.

\section{References}

Buczkowska, J., Kozdrowski, R., Sikora, M.,Dzieciol, M. and Matusz, A. 2015. Non-traditional treatments for endometritis in mares. Bulgarian Journal of Veterinary Medicine 18(4): 285-93.

Card, C. 2005. Post-breeding inflammation 
and endometrial cytology in mares. Theriogenology 64(3): 580-88.

Chastant-Maillard, S. 2006. Is there a future for pharmaceutical management in cow reproduction? European perspective. World Buiatrics Congress, Nice, France: 14-18 October.

Ferris, R. A., MuCce, M. P., Borlee, I. G., Loncar, D. K., Hennet, L. M. and Borlee, R. B. 2016. In vitro efficacy of non-antibiotic treatments on biofilm disruption of gram-negative pathogens and an in vivo model of infectious endometritis utilizing isolates from the equine uterus. Journal of Clinical Microbiology 54(3): 631-39.

Ferris, R. A. 2017.Therapeutics for infectious endometritis: a clinical perspective. Revista. Brasileira Reproducao Animal 41(1): 175-79.

Laugier, C., Foucher, N., Sevin, C., Leon, A. and Tapprest, J. 2011. A 24-year retrospective study of equine abortion in Normandy (France). Journal of Equine Veterinary Science 31(3): 116-23.

LeBlanc, M. M. and Causey, R. C. 2009. Clinical and subclinical endometritis in the mare: both threats to fertility. Reproduction in Domestic Animals 44(s3): 10-22.

Rasmussen, C. D., Petersen, M. R., Bojesen A M, Pedersen, H. G, Lehn-Jensen, H. and Christoffersen, M. 2015. Equine infectious endometritis - clinical and subclinical cases. Journal of Equine Veterinary Science 35(2): 95-104.

Ricketts, S. W. 1999.The treatment of equine endometritis in studfarm practice.Pferdeheilkunde15(6):588-93.

Rutllant, J., Lopez-Bejar, M. and LopezGatius, F. 2005. Ultrastructural andrheological properties of bovine vaginal fluid and its relation tosperm motility and fertilization: a review. Reproduction of Domestic Animal40: 79-86.

Samper, J. C., Pycock, J. F. and McKinnon, A. O. 2007. Current Therapy in Equine Reproduction, Saunders Publisher, Philadelphia, USA, pp 93-104.

Troedsson, M. H. 2007. High risk pregnant mare. ctaVeterinariaScandinavica49(1): 1136-51.

Troedsson, M. H. T. 2011. Endometritis. In: Equine Reproduction, 2ndedn, eds $\mathrm{O}$. McKinnon, E. L. Squires, W. E. Vaala and D. D. Varner, Blackwell Publishing Ltd., pp. 2608-19.

Wolfsdorf, K. andCaudle,A. B. 2007. Inflammation of the tubular reproductive tract of the mare. In: CurrentTherapy in Large Animal Theriogenology, eds R. S. Youngquist and W. R. Threlfall, Saunders Elsevier, Philadelphia, pp. 158-67.

\section{How to cite this article:}

Jugraj Singh Mahal, M. Honparkhe, Ajeet Kumar and Prahlad Singh. 2020. Efficacy of Intrauterine Hydrogen Peroxide and Povidone Iodine Administration to Treat Endometritic Mares. Int.J.Curr.Microbiol.App.Sci. 9(03): 2427-2431. doi: https://doi.org/10.20546/ijcmas.2020.903.277 